\title{
ANALISIS KUALITAS PELAYANAN DAN KEPUASAN KONSUMEN DUNKIN DONUTS GADING SERPONG
}

\author{
ANALYSIS OF SERVICE QUALITY AND CUSTOMER SATISFACTION OF DUNKIN DONUTS \\ STORE IN GADING SERPONG
}

\author{
Abel Gandhy ${ }^{1}$ \\ ${ }^{1}$ Universitas Surya, Grand Serpong Mall, Jln. MH. Thamrin, Tangerang, Banten, Indonesia \\ email: abel.gandhy@surya.ac.id
}

DOI : 10.30998/jmil.v2i1.81

\begin{abstract}
ABSTRAK
Penelitian ini bertujuan untuk mengetahui kualitas pelayanan dan tingkat kepuasan konsumen gerai Dunkin Donuts cabang Gading Serpong. Kualitas pelayananterdiri dari tangible, reliability, responsiveness, assurance, dan empathy. Waktu dan tempat penelitian dilakukan pada Dunkin Donuts Gading Serpong dari April-Juli 2017. Responden yang dijadikan sampel penelitian berjumlah 100 orang. Data dianalsis dengan metode Index Performance Analysis (IPA) dan Customer Satisfaction Index (CSI). Pelayanan yang diberikan oleh gerai dunkin donuts Gading Serpong secara keseluruhan dikategorikan baik, karena dapat memenuhi harapan dari konsumennya. Nilai Customer Satisfaction Index yang diperoleh adalah $86.76 \%$. Hal ini menggambarkan pelanggan Dunkin Donuts di Gading Serpongmerasa sangat puas dengan kinerja kualitas pelayanan yang diberikan oleh gerai Dunkin Donuts Gading Serpong. Perbaikan pelayanan yang perlu dilakukan adalah kecepatan karyawan dalam menangani keluhan pelanggan, meningkatkan kebersihan fasilitas toilet, dan meningkatkan keramahan karyawan ketika sedang melayani konsumen.
\end{abstract}

Kata kunci: Kualitas pelayanan, Kepuasan Konsumen, Dunkin Donuts

\begin{abstract}
This study aims to determine service quality and customer satisfaction of Dunkin Donuts customer in Gading Serpong. Service quality are consists of tangible, reliability, responsiveness, assurance, and empathy. Research conducted at Dunkin Donuts Gading Serpong from April-July 2017. Respondents are used as research samples amounted to 100 people. Data were processed by using Index Performance Analysis (IPA) and Customer Satisfaction Index (CSI) method. Overall, the services provided by dunkin donuts outlet in Gading Serpong is good, because they can meet the expectations of their customer. The value of Customer Satisfaction Index (CSI) is $86.76 \%$. This illustrate that Dunkin Donuts customers in Gading Serpong are very satisfied with the service quality performance provided by Dunkin Donuts. Improvement of services that need to be done is the speed of employees in handling customer complaints, improving the cleanliness of toilet facilities, and improving employee friendliness while serving customers
\end{abstract}

Keywords: Service Quality, Consumer Satisfaction, Dunkin Donuts 


\section{PENDAHULUAN}

Donat merupakan salah satu produk olahan dari tepung terigu yang banyak digemari mulai dari anak-anak hingga orang dewasa. Oleh karena itu

semakin mengalami perkembangan, salah satunya pada tempat atau lokasi penjualan. Donat dijual mulai dari pedagang biasa hingga perusahaan donat berkelas, seperti Dunkin Donuts, J.Co, Donat Madu, Krispy Kreme, dan lain sebagainya. Ketatnya persaingan pada saat ini membuat perusahaan harus selalu mencoba memberikan pelayanan terbaik kepada para konsumen (Utami \& Jatra, 2015).

Kualitas pelayanan menjadi salah satu aspek penting dalam keberhasilan suatu usaha. Adapun kualitas pelayanan adalah suatu upaya dalam memenuhi kebutuhan dan keinginan konsumen serta ketepatan penyampaiannya untuk mengimbangi harapan konsumen. Dimensi kualitas pelayanan yang terdiri dari tangible, reliability, responsiveness, assurance, dan empathy diharapkan dapat memenuhi harapanharapan konsumen dalam memenuhi kebutuhan dan keinginannya. Kualitas pelayanan dikatakan baik jika perusahaan dapat memberikan pelayanan yang sesuai dengan harapan konsumen sehingga konsumen merasa puas (Adi, 2012).

Kepuasan konsumen merupakan salah satu aspek penting dalam mempertahankan suatu usaha atau bisnis yang sedang dikembangkan. Karena apabila konsumen merasa puas terhadap produk dan pelayanan dari pelaku usaha, maka konsumen akan mempertahankan loyalitasnya untuk perusahaan tersebut. Dari pelayanan yang dapat memuaskan konsumen akan berdampak pada peningkatan penjualan produk suatu perusahaan (Adriani, 2012). Misalnya dalam dimensi tangible, fasilitas yang memadai, modern, dan terlihat menarik dapat dipandang sebagai hal yang positif dan dapat membuat konsumen merasa puas dengan fasilitas yang ditawarkan tersebut. Pada dimensi assurance, ketika karyawan perusahaan memberikan pelayanan yang terjamin pada setiap transaksi yang dilakukan, konsumen dapat merasa aman dan puas dengan layanan yang diberikan. Selain itu pada dimensi empathy, ketika karyawan perusahaan mendapatkan perhatian individual dan adanya peningkatan komunikasi antara manajemen dan pelanggan dapat membuat konsumen merasa lebih puas. Pada dimensi reliability, ketepatan dan kecepatan dalam menyelesaikan pesanan dapat menjadi faktor penting dalam mempertahankan konsumen. donat diciptakan dengan berbagai rasa dan varian yang menarik bagi semua kalangan. Harga yang ditawarkan pun bervariasi sesuai dengan kualitas produk dan kualitas pelayanan yang ditawarkan oleh penjual donat. Semakin berkembangnya zaman, donat

Kemudian pada dimensi responsiveness, kesediaan dan kesiapan karyawan untuk memberikan layanan kepada pelanggan dengan inisiatif sendiri dapat mempengaruhi tingkat kepuasan konsumen (Selvakumar, 2015). Perusahaan perlu mengetahui tingkat pelayanan dan kepuasan konsumen karena berkaitan erat dengan keberlangsungan hidup dari perusahaan (Winarno dan Absor, 2017).

Menganalisis kualitas pelayanan dan kepuasan konsumen penting bagi produsen untuk mengetahui apakah konsumen merasa puas atau sebaliknya sehingga pada akhirnya perbaikan yang dilakukan dapat menciptakan konsumen yang loyal. Lokasi penelitian yang dipilih adalah gerai Dunkin Donuts cabang Gading Serpong. Pemilihan lokasi penelitian didasarkan pengunjung yang selalu ramai serta lokasi gerai yang strategis, yakni dekat dengan sekolah, universitas, perkantoran, dan perumahan. Sehingga para masyarakat Gading Serpong lebih mudah dalam menjangkau gerai tersebut. Penelitian ini membahas kualitas pelayanan serta tingkat kepuasan pelanggan gerai Dunkin Donuts cabang Gading Serpong.

\section{METODOLOGI PENELITIAN}

\section{Waktu dan Lokasi Penelitian}

Lokasi penelitian ini dilakukan pada Dunkin Donuts di daerah Gading Serpong, Tangerang Selatan. Penelitian ini dilaksanakan pada April Juli 2016.

\section{Metode Pengumpulan Data}

Sumber data penelitian ini berasal dari berbagai sumber meliputi literatur-literatur, dan proses pembelajaran lainnya. Adapun metode yang digunakan dalam penelitian ini dilakukan dengan cara sebagai berikut: a. Metode Wawancara dan Kuesioner Wawancara dilakukan dengan para konsumen dari Dunkin Donuts guna untuk mengetahui karakteristik konsumen Dunkin Donuts Gading Serpong. Kuesioner dalam penelitian ini dilakukan untuk mengetahui informasi-informasi penting terkait dengan pelayanan yang diberikan oleh Dunkin Donuts melalui dimensi-dimensi kualitas pelayanan. 
pengukuran yang digunakan dalam kuesioner untuk semua indikator pada masing-masing variabel adalah skala likert (skala 1-5).

\section{Teknik Pengambilan Sampel}

Metode penentuan responden pada penelitian ini menggunakan purposive sampling, yaitu teknik mengambil sampel dengan tidak berdasarkan random, daerah atau strata, melainkan berdasarkan atas adanya pertimbangan yang berfokus pada tujuan tertentu (Sulistyo, 2011). Responden dalam penelitian ini adalah konsumen dari Dunkin Donuts yang berlokasi di daerah Gading Serpong. Kriteria responden yang digunakan peneliti adalah konsumen yang sudah pernah melakukan pembelian di Dunkin Donuts minimal 2 kali dan berumur 17-50 tahun dengan pertimbangan pada usia tersebut responden dapat memahami pernyataan serta memberikan penilaian yang objektif pada kuesioner. Adapun rumus untuk menentukan jumlah responden adalah $50+8(\mathrm{n})$, dimana $\mathrm{n}$ adalah jumlah variabel penelitian, maka diperoleh perhitungan sebagai berikut (Green (1991) dalam Sasongko dan Subagjo 2013, 3): Jumlah sampel $=50+8(\mathrm{n})=$ $50+8(6)=98$ responden.

\section{Metode Analisis Data}

\section{a. Uji Validitas}

Uji Validitas adalah ketepatan suatu instrument dalam pengukuran. Uji ini dilakukan pada setiap pernyataan-pernyataan kuesioner dengan jalan menghitung koefisien relasi dari tiap pernyataan dengan skor total yang diperoleh, kemudian dibandingkan dengan angka kritis untuk mengukur sah atau tidaknya Skala suatu kuesioner (Sulistyo, 2011, 40). Dasar pengambilan keputusan untuk menguji validitas adalah, jika $r$ hitung positif dan $r$ hitung $>r$ tabel, maka variabel tersebut valid. Sedangkan Jika $r$ hitung tidak positif serta $r$ hitung $<r$ tabel, maka variabel tersebut tidak valid.

\section{b. Uji Reliabilitas}

Uji reliabilitas adalah alat untuk mengukur suatu kuesioner yang merupakan indikator dari variabel guna untuk mengetahui konsistensinya (Sulistyo, 2011, 46). Adapun cara yang digunakan untuk menguji reliabilitas kuesioner dalam penelitian ini adalah dengan menggunakan rumus koefisien Alpha Cronbach, yaitu jika hasil koefisien Alpha > taraf signifikasni 60\% atau 0,6 maka kuesioner tersebut dikatakan reliable. Sedangkan, jika hasil koefisien Alpha < taraf signifikasni $60 \%$ atau 0,6 maka kuesioner tersebut dikatakan tidak reliable.

\section{Importance Perfomance Analysis (IPA)}

Importance Performance Analysis (IPA) merupakan suatu metode untuk mengukur atribut menurut tingkat kepentingan dan kinerja atau tingkat kepuasan pelanggan, berguna untuk mengembangkan strategi pemasaran yang efektif bagi perusahaan (Rijanto, 2014, 82). Pada IPA, hasil penilaian tingkat kepentingan dan kinerja atribut dibentuk menjadi suatu diagram. Sumbu mendatar $(\overline{\mathrm{x}})$ disisi skor rataan tingkat kinerja aktual, dan sumbu tegak ( $\bar{y})$ disisi skor rataan tingkat kepentingan atribut. Berikut merupakan rumus sumbu $\overline{\mathrm{x}}$ dan $\overline{\mathrm{y}}$ :

$$
\bar{Y}=\frac{\sum_{i=1}^{n} Y_{i}}{n} \quad \text { dan } \quad \bar{X}=\frac{\sum_{i=1}^{n} X_{i}}{n}
$$

Keterangan:

$\overline{\mathrm{x}}$ : skor rata-rata tingkat pelaksanaan/kinerja

$\overline{\mathrm{y}}$ : skor rata-rata tingkat kepentingan

$\mathrm{n}$ : jumlah responden

Diagram kartesius dibatasi juga dengan dua garis yang berpotongan tegak sehingga menjadi suatu bangun yang memiliki empat bagian. Setiap atribut kemudian dijabarkan ke dalam diagram kartesius IPA untuk mengetahui letak kuadran dari masing-masing atribut.

Analisis ini dipetakan menjadi 4 kuadran untuk seluruh variabel yang mempengaruhi kualitas suatu produk, pelayanan, atau jasa. Pembagian kuadran dalam Importance Performance Analysis dapat dikategorikan sebagai berikut: 


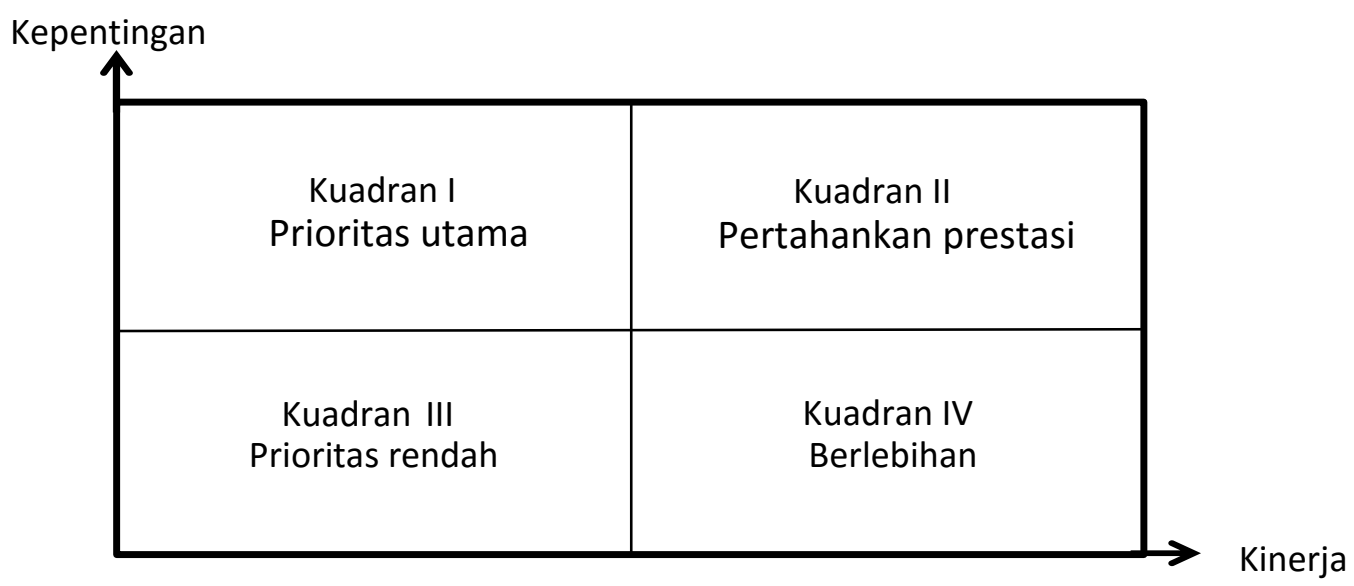

Gambar 1. Peta Importance Performance

\section{Kuadran I (Concentrate these)}

Kuadran I merupakan wilayah dimana memuat faktor yang dianggap penting oleh konsumen namun masih belum sesuai dengan konsumen sehingga harus dilakukan peningkatan mutu.

\section{Kuadran II (Keep Up The Good Work)}

Kuadran II adalah wilayah dimana konsumen merasa bahwa ekspetasinya terhadap produk susah sesuai dengan kinerja produk yang dihasilkan sejingga menghasilkan tingkay kepuasanyang relatif tinggi. Dalam hal ini variabel harus dipertahankan akrena menjadikan produk memiliki nilai jual unggul.

\section{Kuadran III (Low Priority)}

Kuadran III adalah kuadran yang meuat faktor yang dianggap tidak terlalu penting oleh konsumen dan tidak memiliki kinerja yang optimum pada realitanya. Faktor-faktor pada kuadran ini tidak meingkatkan kepuasan konsumen secara signifikan sehingga keberadaan faktor ini perlu dipertimbangkan kembali.

4. Kuadran IV (Possible Overkill)
Kuadran IV memuat faktor yang dianggap kurang penting oleh konsumen dan dirasa terlalu berlebihan. Keberadaan faktor atau variabel ini dapat diminimalisir keberadaanya atau ditiadakan agar dapat menghemat outcome dari produksi.

\section{HASIL DAN PEMBAHASAN}

\section{Customer Satisfaction Index (CSI)}

Merupakan analisis kuantitatif berupa persentase pelanggan yang puas dalam suatu survey kepuasan pelanggan. CSI diperlukan untuk mengetahui tingkat kepentingan atribut-atribut produk atau jasa (Pohandry, 2013, 22). Kepuasan pelanggan kemudian dihitung dengan tahap sebagai berikut (Anggraini, et al, 2015, 77):

1. Menghitung Weight Factor, yaitu mengubah nilai rata-rata tingkat kepentingan menjadi angka persen, sehingga didapatkan total Weighting Factor $100 \%$.

2. Menghitung Weighting Score, yaitu nilai perkalian antara nilai rata-rata tingkat kinerja dengan weighting factor.

3. Menghitung weighted total, yaitu menjumlahkan weighted score dari semua atribut. 4. Menghitung Satisfaction index, yaitu weighted total dibagi skala maksimal yang digunakan (dalam penelitian ini skala maksimum yang digunakan adalah 5) kemudian dikali $100 \%$

\section{Karakteristik Responden}

Responden yang digunakan pada penelitian ini berjumlah 100 orang. 
Tabel.1. Profil responden berdasarkan jenis kelamin dan usia

\begin{tabular}{rlccccc}
\hline No & Jenis & & & & & \\
\hline 1 & Laki-Laki & 42 & $43 \%$ & $17-25$ & 78 & $80 \%$ \\
\hline 2 & Perempuan & 56 & $57 \%$ & $26-40$ & 10 & $10 \%$ \\
\hline & Jumlah & 98 & $100 \%$ & U > 40 & 10 & $10 \%$ \\
\hline & & & Jumlah & 98 & $100 \%$ \\
\hline
\end{tabular}

Tabel.2. Profil responden berdasarkan pekerjaan dan pendapatan

\begin{tabular}{rlccccc}
\hline No & Pekerjaan & Jumlah & Presentase & Pendapatan & Jumlah & Presentase \\
\hline 1 & Pelajar/Mahasiswa & 71 & $73 \%$ & $\mathrm{P}<1.000 .000$ & 30 & $30 \%$ \\
\hline 2 & Pegawai Swasta & 12 & $12 \%$ & $1.000 .000-3.000 .000$ & 49 & $50 \%$ \\
\hline 3 & Wiraswasta & 8 & $8 \%$ & $3.000 .000-5.000 .000$ & 11 & $12 \%$ \\
\hline 4 & Pegawai Negeri & 6 & $6 \%$ & $\mathrm{P}>5.000 .000$ & 8 & $8 \%$ \\
\hline 5 & Ibu Rumah Tangga & 1 & $1 \%$ & & 98 & \\
\hline \multicolumn{7}{c}{} \\
\hline
\end{tabular}

\section{Analisis Uji Validitas}

Tabel 3. Uji Validitas Kuesioner Bukti Fisik (Tangible)

\begin{tabular}{cccc}
\hline $\begin{array}{c}\text { Item } \\
\text { Pernyataan }\end{array}$ & $\begin{array}{c}\text { Nilai } \\
\text { Factor } \\
\text { Loading }\end{array}$ & $\begin{array}{c}\mathrm{R} \\
\text { Tabel }\end{array}$ & Keterangan \\
BF1 & 0.469 & 0.361 & $\begin{array}{c}\text { Item } \\
\text { Vernyataan } \\
\text { Valid }\end{array}$ \\
\hline BF2 & 0.548 & 0.361 & $\begin{array}{c}\text { Pernyataan } \\
\text { Valid }\end{array}$ \\
\hline BF3 & 0.546 & 0.361 & $\begin{array}{c}\text { Pernyataan } \\
\text { Valid }\end{array}$ \\
\hline BF4 & 0.567 & 0.361 & $\begin{array}{c}\text { Item } \\
\text { Valid }\end{array}$ \\
\hline & & & \\
\hline
\end{tabular}

Pada variabel bukti fisik memiliki 4 pernyataan, yang terdiri dari toilet yang tersedia, akses Wifi, tempat ibadah, penampilan karyawan Dunkin Donuts. Nilai Loading Factor dan dan R Tabel disajikan pada Tabel 3.

Pada variabel keandalan terdapat 4 item pernyataan yang terdiri dari kemampuan dalam memberikan pelayanan kepada konsumen, kemampuan dalam memberikan informasi kepada konsumen, ketepatan waktu pemesanan (cepat atau lambat), dan sikap karyawan dalam melayani konsumen.

Tabel 4. Uji Validitas Kuesioner Keandalan (Reliability)

\begin{tabular}{cccc}
\hline $\begin{array}{c}\text { Item } \\
\text { Pernyataan }\end{array}$ & $\begin{array}{l}\text { Nilai Factor } \\
\text { Loading }\end{array}$ & R Tabel & Keterangan \\
\hline K1 & 0.681 & 0.361 & $\begin{array}{c}\text { Item } \\
\text { Pernyataan } \\
\text { Valid }\end{array}$ \\
\hline K2 & 0.559 & 0.361 & $\begin{array}{c}\text { Item } \\
\text { Pernyataan } \\
\text { Valid }\end{array}$ \\
& & & \\
\hline
\end{tabular}




\begin{tabular}{cccc}
\hline K3 & 0.617 & 0.361 & $\begin{array}{c}\text { Item } \\
\text { Pernyataan } \\
\text { Valid }\end{array}$ \\
\hline K4 & 0.710 & 0.361 & $\begin{array}{c}\text { Item } \\
\text { Pernyataan } \\
\text { Valid }\end{array}$ \\
& & & \\
\hline
\end{tabular}

Pada variabel daya tanggap terdiri dari 3 item pernyataan, yaitu karyawan dalam menanggapi permintaan pelanggan, kecepatan dalam memberikan jasa kepada konsumen, kecepatan ketepatan dan kesediaan karyawan dalam menangani keluhan pelanggan. Tabel 5 menjelaskan uji validitas setiap item pernyataan untuk variabel Responsiveness.

Tabel 5. Uji Validitas Kuesioner Daya Tanggap (Responsiveness)

\begin{tabular}{|c|c|c|c|}
\hline $\begin{array}{l}\text { Item } \\
\text { Pernyataan }\end{array}$ & $\begin{array}{l}\text { Nilai Factor } \\
\text { Loading }\end{array}$ & R Tabel & Keterangan \\
\hline DT1 & 0.665 & 0.361 & $\begin{array}{l}\text { Item } \\
\text { Pernyataan } \\
\text { Valid }\end{array}$ \\
\hline DT2 & 0.691 & 0.361 & $\begin{array}{l}\text { Item } \\
\text { Pernyataan } \\
\text { Valid }\end{array}$ \\
\hline DT3 & 0.633 & 0.361 & $\begin{array}{l}\text { Item } \\
\text { Pernyataan } \\
\text { Valid }\end{array}$ \\
\hline
\end{tabular}

Pada variabel jaminan terdapat 3 item pernyataan yang terdiri dari keamanan dari gerai Dunkin Donuts, terjaminnya mutu makanan dan minuman yang tersedia, dan keamanan dalam bertransaksi.

Tabel 6. Uji Validitas Kuesioner Jaminan (Assurance)

\begin{tabular}{crrl}
\hline $\begin{array}{c}\text { Item } \\
\text { Pernyataan }\end{array}$ & $\begin{array}{c}\text { Nilai Factor } \\
\text { Loading }\end{array}$ & $\begin{array}{c}\mathrm{R} \\
\text { Tabel }\end{array}$ & Keterangan \\
\hline $\mathrm{J} 1$ & 0.489 & 0.361 & $\begin{array}{l}\text { Item } \\
\text { Pernyataan } \\
\text { Valid }\end{array}$ \\
& & & \\
\hline $\mathrm{J} 2$ & 0.534 & 0.361 & $\begin{array}{l}\text { Item } \\
\text { Pernyataan } \\
\text { Valid }\end{array}$ \\
& & & Item \\
& & & $\begin{array}{l}\text { Pernyataan } \\
\text { Valid }\end{array}$ \\
\hline J3 & 0.542 & 0.361 & \\
& & & \\
\hline
\end{tabular}

Pada variabel empati terdapat 4 item pernyataan yang terdiri dari perhatian karyawan terhadap konsumen yang membutuhkan pelayanan, cepat tanggapnya karyawan dalam memenuhi kebutuhan pelanggan, karyawan memperlakukan pelanggan (sama atau tidak) dan komunikasi yang baik antar karyawan dengan pelanggan.

Tabel 7. Uji Validitas Kuesioner Empathy)

\begin{tabular}{|c|c|c|c|}
\hline $\begin{array}{l}\text { Item } \\
\text { Pernyataan }\end{array}$ & $\begin{array}{l}\text { Nilai Factor } \\
\text { Loading }\end{array}$ & $\begin{array}{l}\mathrm{R} \\
\text { Tabel }\end{array}$ & Keterangan \\
\hline E1 & 0.584 & 0.361 & $\begin{array}{l}\text { Item } \\
\text { Pernyataan } \\
\text { Valid }\end{array}$ \\
\hline E2 & 0.572 & 0.361 & $\begin{array}{l}\text { Item } \\
\text { Pernyataan } \\
\text { Valid }\end{array}$ \\
\hline E3 & 0.747 & 0.361 & $\begin{array}{l}\text { Item } \\
\text { Pernyataan } \\
\text { Valid }\end{array}$ \\
\hline E4 & 0.566 & 0.361 & $\begin{array}{l}\text { Item } \\
\text { Pernyataan } \\
\text { Valid }\end{array}$ \\
\hline
\end{tabular}

Tabel 8. Uji Reliabilitas Kuesioner

$\begin{array}{lll}\text { Variabel Nilai Alpha } & \text { Keterangan }\end{array}$




\begin{tabular}{ccc}
\hline Bukti Fisik & 0.684 & Seluruh item pernyataan dalam variabel ini dapat diandalkan \\
\hline Keandalan & 0.797 & Seluruh item pernyataan dalam variabel ini dapat diandalkan \\
\hline $\begin{array}{c}\text { Daya } \\
\text { Tanggap }\end{array}$ & 0.785 & Seluruh item pernyataan dalam variabel ini dapat diandalkan \\
\hline Jaminan & 0.775 & Seluruh item pernyataan dalam variabel ini dapat diandalkan \\
\hline Empati & 0.820 & Seluruh item pernyataan dalam variabel ini dapat diandalkan \\
\hline
\end{tabular}

\section{Analisis Uji Reliabilitas}

Uji reliabilitas adalah alat untuk mengukur suatu kuesioner yang merupakan indikator dari variabel guna untuk mengetahui konsistensinya. Berikut adalah hasil perhitungan uji reliabilitas yang diolah menggunakan software SPSS 22. Secara keseluruhan nilai reliabilitas keseluruhan yang didapatkan sebesar 0.866, yang berarti seluruh item pernyataan dalam seluruh variabel ini dapat diandalkan, karena nilainya sudah berada diatas 0,6. Hasil Uji Reliabilitas untuk setiap variabel disajikan dalam tabel 9.

\section{Importance Perfomance Analysis (IPA)}

Importance Performance Analysis merupakan suatu metode untuk mengukur atribut menurut tingkat kepentingan dan kinerja atau tingkat kepuasan pelanggan, berguna untuk mengembangkan strategi pemasaran yang efektif bagi perusahaan (Rijanto, 2014, 82). Berikut adalah hasil perhitungan IPA yang disajikan kedalam tabel dan diagram:

Tabel 9. Hasil Perhitungan Index Performance Analysis (IPA)

\begin{tabular}{clcc}
\hline No & \multicolumn{1}{c}{ Kode } & $\begin{array}{c}\text { Kinerja } \\
(\mathrm{X})\end{array}$ & $\begin{array}{c}\text { Kepentingan } \\
(\mathrm{Y})\end{array}$ \\
\hline 1 & Kebersihan Toilet yang tersedia & 3,58 & 4,4 \\
\hline 2 & Akses Wifi yang cepat & 3,94 & 4,44 \\
\hline 3 & Tempat Ibadah yang Nyaman & 2,15 & 4,14 \\
\hline 4 & Penampilan karyawan Dunkin Donuts Rapih & 3,57 & 4,07 \\
\hline 5 & $\begin{array}{l}\text { Kemampuan dalam memberikan pelayanan kepada } \\
\text { konsumen }\end{array}$ & 3,82 & 4,35 \\
\hline 6 & $\begin{array}{l}\text { Kemampuan memberikan informasi kepada } \\
\text { konsumen }\end{array}$ & 3,75 & 4,26 \\
\hline 7 & Ketepatan waktu pemesanan (cepat atau lambat) & 3,76 & 4,42 \\
\hline 8 & Sikap karyawan dalam melayani konsumen & 3,65 & 4,35 \\
\hline 9 & Karyawan dalam menanggapi permintaan pelanggan & 3,69 & 4,32 \\
\hline 10 & Kecepatan memberikan jasa kepada konsumen & 3,65 & 4,35 \\
\hline 11 & $\begin{array}{l}\text { Kecepatan, ketepatan, dan kesediaan karyawan dalam } \\
\text { menangani keluhan pelanggan }\end{array}$ & 3,6 & 4,39 \\
\hline 12 & Keamanan dari gerai Dunkin Donuts & 4,03 & 4,51 \\
\hline 13 & $\begin{array}{l}\text { Terjaminnya mutu makanan dan minuman yang } \\
\text { tersedia }\end{array}$ & 4,06 & 4,5 \\
\hline 14 & Keamanan dalam bertransaksi & 4,05 & 4,55 \\
\hline 15 & $\begin{array}{l}\text { Perhatian karyawan pada konsumen yang } \\
\text { membutuhkan pelayanan }\end{array}$ & 3,45 & 4,33 \\
\hline
\end{tabular}




\begin{tabular}{clcc}
16 & $\begin{array}{l}\text { Cepat tanggapnya karyawan dalam memenuhi } \\
\text { kebutuhan pelanggan }\end{array}$ & 3,51 & 4,25 \\
\hline 17 & Karyawan memperlakukan pelanggan dengan baik & 3,6 & 4,26 \\
\hline 18 & $\begin{array}{l}\text { Komunikasi yang baik antar karyawan dengan } \\
\text { pelanggan }\end{array}$ & 3,55 & 4,26 \\
\hline 19 & $\begin{array}{l}\text { Saya puas dengan pelayanan yang diberikan Dunkin } \\
\text { Donuts Gading Serpong }\end{array}$ & 3,85 & 4,33 \\
\hline 20 & $\begin{array}{l}\text { Saya akan merekomendasikan Dunkin Donuts kepada } \\
\text { orang lain disekitar saya }\end{array}$ & 3,6 & 4,12 \\
\hline
\end{tabular}

Langkah selanjutnya adalah melakukan pengelompokkan item pernyataan hasil perhitungan IPA pada diagram kartesius. Tujuan digunakannya diagram kartesius adalah untuk memudahkan melihat atribut-atribut yang tersebar pada 4 kuadran.

a. Kuadran I Merupakan kuadran yang memiliki tingkat kepuasan yang masih sangat rendah sehingga menjadi prioritas utama untuk dilakukan perbaikan. Terdapat 3 Atribut yang ada dalam kuadran I. Adapun atribut yang harus diperbaiki untuk meningkatkan kepuasan konsumen adalah meningkatkan kebersihan toilet, kecepatan karyawan dalam menangani keluhan pelanggan dan meningkatkan keramahan karyawan ketika sedang melayani konsumen.

b. Kuadran II merupakan kuadran yang diharapkan oleh pelanggan dan telah sesuai dengan yang dirasakan oleh para pelanggan tersebut. Terdapat 8 atribut yang ada dalam kuadran II. Atribut-atribut yang terdapat pada kuadran ini harus dipertahankan oleh perusahaan. Atribut tersebut adalah akses wifi yang cepat, kemampuan dalam memberikan layanan kepada konsumen, kemampuan dalam memberikan informasi kepada konsumen, ketepatan waktu dalam melayani konsumen, karyawan dalam menanggapi permintaan pelanggan, kecepatan memberikan jasa kepada konsumen, keamanan dari gerai Dunkin Donuts, terjaminnya mutu makanan dan minuman yang tersedia, keamanan dalam bertransaksi, dan konsumen merasa puas dengan pelayanan yang diberikan oleh Dunkin Donuts Gading Serpong.

c. Kuadran III merupakan kuadran dengan prioritas rendah karena memuat atributatribut yang dianggap kurang penting oleh pelanggan dan pada kenyataannya kinerjanya tidak terlalu istimewa. Terdapat 6 atribut dalam kuadran III. Atribut tersebut adalah tempat ibadah, penampilan karyawan Dunkin Donuts, cepat tanggapnya karyawan dalam memenuhi kebutuhan pelanggan, karyawan memperlakukan pelanggan (sama atau tidak), komunikasi yang baik antar karyawan dengan pelanggan, dan pelanggan akan merekomendasikan Dunkin Donuts kepada orang lain disekitarnya.

d. Atribut pada kuadran IV mempunyai tingkat kepentingan yang rendah, tetapi memiliki tingkat pelaksanaan kinerja tinggi. Terdapat 1 Atribut yang ada dalam kuadran IV. Atribut yang terdapat pada kuadran ini dianggap berlebihan dan harus dikurangi kinerjanya. Atribut tersebut adalah kemampuan memberikan informasi kepada konsumen.

Persebaran atribut-atribut pernyataan setiap variabel dalam setiap kuadran disajikan pada gambar 2. 


\section{Importance Performance Analysis}

Kuadran I:

Prioritas tinggi

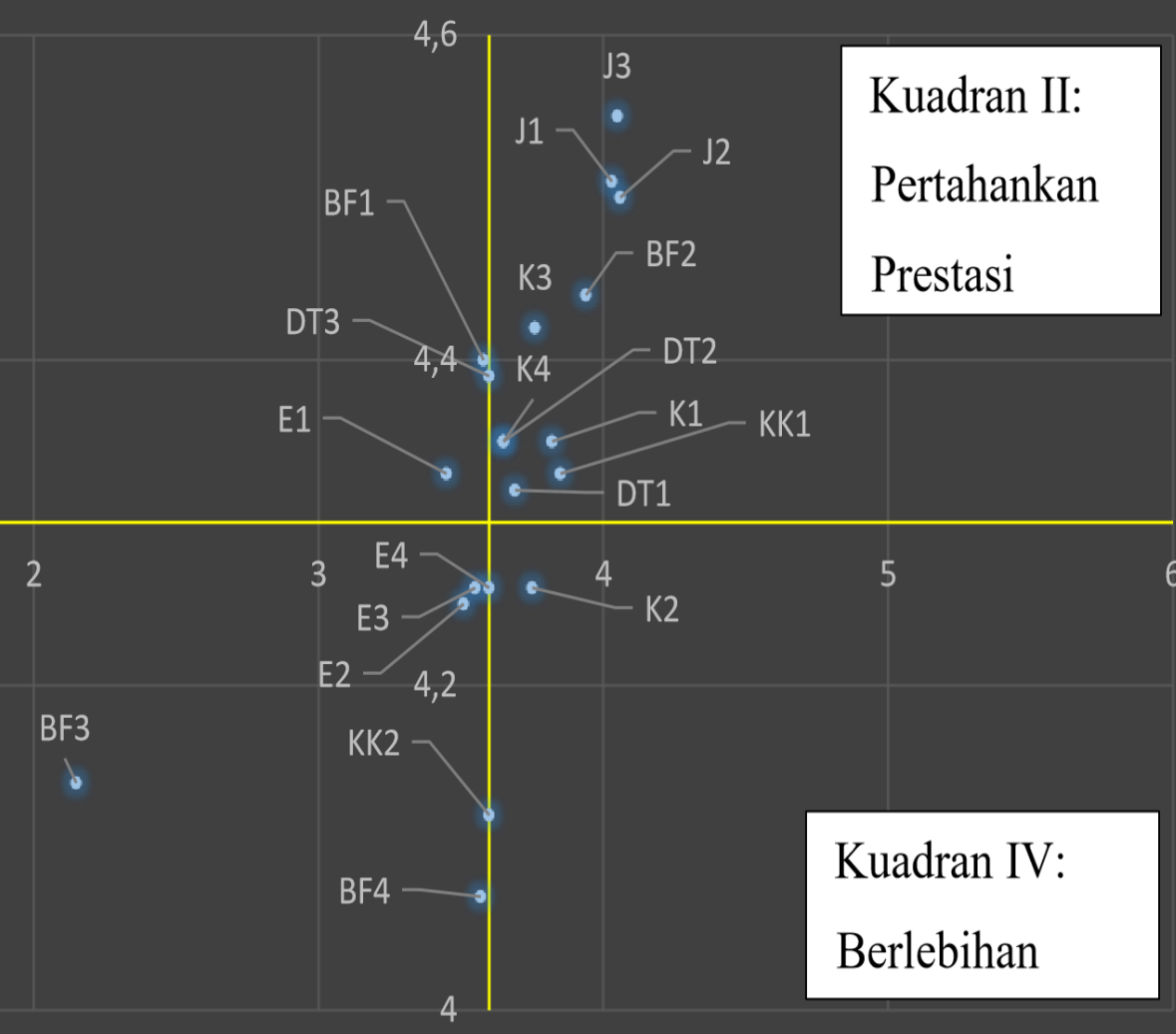

Gambar 2. Persebaran atribut pada setiap kuadran

\section{Customer Satisfaction Index (CSI)}

Customer Satisfaction Index (CSI) merupakan analisis kuantitatif berupa persentase pelanggan yang puas dalam suatu survey kepuasan pelanggan. CSI diperlukan untuk mengetahui tingkat kepentingan atributatribut produk atau jasa (Pohandry, 2013, 22). Tabel 10 menampilkan hasil perhitungan Customer Satisfaction Index:

Tabel 10. Hasil Perhitungan Customer Satisfaction Index (CSI)

\begin{tabular}{clccc}
\hline No & \multicolumn{1}{c}{ Kode } & $\begin{array}{c}\text { Kinerja } \\
(\mathrm{X})\end{array}$ & $\begin{array}{c}\text { Kepentingan } \\
(\mathrm{Y})\end{array}$ & Skor \\
\hline 1 & Kebersihan Toilet yang tersedia & 3,58 & 4,4 & 15,75 \\
\hline 2 & Akses Wifi Baik & 3,94 & 4,44 & 17,49 \\
\hline 3 & Tempat Ibadah yang Nyaman & 2,15 & 4,14 & 8,9 \\
\hline 4 & Penampilan karyawan Dunkin Donuts Rapih & 3,57 & 4,07 & 14,53 \\
\hline 5 & $\begin{array}{l}\text { Kemampuan dalam memberikan layanan kepada } \\
\text { konsumen }\end{array}$ & 3,82 & 4,35 & 16,62 \\
\hline 6 & $\begin{array}{l}\text { Kemampuan memberikan informasi kepada } \\
\text { konsumen }\end{array}$ & 3,75 & 4,26 & 15,98 \\
\hline 7 & Ketepatan waktu pemesanan (cepat atau lambat) & 3,76 & 4,42 & 16,62 \\
\hline 8 & Sikap karyawan dalam melayani konsumen & 3,65 & 4,35 & 15,88 \\
\hline
\end{tabular}




\begin{tabular}{clccc}
9 & $\begin{array}{l}\text { Karyawan dalam menanggapi permintaan } \\
\text { pelanggan }\end{array}$ & 3,69 & 4,32 & 15,94 \\
\hline 10 & Kecepatan memberikan jasa kepada konsumen & 3,65 & 4,35 & 15,88 \\
\hline 11 & $\begin{array}{l}\text { Kecepatan, ketepatan, dan kesediaan karyawan } \\
\text { dalam menangani keluhan pelanggan }\end{array}$ & 3,6 & 4,39 & 15,8 \\
\hline 12 & Keamanan dari gerai Dunkin Donuts & 4,03 & 4,51 & 18,18 \\
\hline 13 & $\begin{array}{l}\text { Terjaminnya mutu makanan dan minuman yang } \\
\text { tersedia }\end{array}$ & 4,06 & 4,5 & 18,27 \\
\hline 14 & Keamanan dalam bertransaksi & 4,05 & 4,55 & 18,43 \\
\hline 15 & $\begin{array}{l}\text { Perhatian karyawan pada konsumen yang } \\
\text { membutuhkan pelayanan }\end{array}$ & 3,45 & 4,33 & 14,94 \\
\hline 16 & $\begin{array}{l}\text { Cepat tanggapnya karyawan dalam memenuhi } \\
\text { kebutuhan pelanggan }\end{array}$ & 3,51 & 4,25 & 14,92 \\
\hline 17 & $\begin{array}{l}\text { Karyawan memperlakukan pelanggan dengan } \\
\text { baik }\end{array}$ & 3,6 & 4,26 & 15,34 \\
\hline 18 & $\begin{array}{l}\text { Komunikasi yang baik antar karyawan dengan } \\
\text { pelanggan }\end{array}$ & 3,55 & 4,26 & 15,12 \\
\hline 19 & $\begin{array}{l}\text { Saya puas dengan pelayanan yang diberikan } \\
\text { Dunkin Donuts Gading Serpong }\end{array}$ & 3,85 & 4,33 & 16,67 \\
\hline 20 & $\begin{array}{l}\text { Saya akan merekomendasikan Dunkin Donuts } \\
\text { kepada orang lain disekitar saya }\end{array}$ & 3,6 & 4,12 & 14,83 \\
\hline & \begin{tabular}{l} 
Total \\
\hline
\end{tabular}
\end{tabular}


$C S I=\frac{316,08}{5 \times 72,86} \times 100 \%=86,76 \%$

Nilai CSI yang diperoleh adalah $86,76 \%$. Hal ini menggambarkan pelanggan Dunkin Donuts merasa sangat puas dengan kinerja yang diberikan oleh Dunkin Donuts, tetapi harus ada perbaikan serta peningkatan pada atribut-atribut yang terdapat pada dimensi kualitas pelayanan. Hasil CSI yang didapatkan diperkuat dengan penelitian yang dilakukan oleh Rijanto (2014) yang menyatakan bahwa nilai CSI diatas 0,81 atau persentase diatas $81 \%$ menyatakan konsumen sangat puas dengan kinerja yang diberikan. Kinerja yang baik tersebut perlu dipertahankan, karena dengan persaingan bisnis yang semakin ketat, diperlukan pelayanan yang prima untuk memenuhi harapan konsumen (Wicaksono, 2017).

\section{Implikasi Manajerial Untuk Dunkin Donuts Gading Serpong}

Hasil analisis dari dimensi-dimensi kualitas pelayanan didapatkan hasil uji parsial terdapat 3 variabel yang berpengaruh terhadap kepuasan konsumen, yaitu bukti fisik, jaminan, dan empati. Berdasarkan hal tersebut dapat dilakukan beberapa implikasi manajerial yang dapat diaplikasikan pada gerai Dunkin Donuts Gading Serpong. Pada bukti fisik, gerai Dunkin Donuts harus memperbaiki toilet yang dirasakan konsumen kurang nyaman, selain itu Dunkin Donuts harus mempertahankan kecepatan wifi pada gerai tersebut karena kebanyakan pelanggan ialah orang-orang yang gemar menggunakan internet. Pada variable jaminan, Dunkin Donuts bisa memaksimal fungsi CCTV untuk menjamin keamanan konsumen dalam melakukan berbagai kegiatan didalam gerai tersebut, selain itu pada lahan parkir sebaiknya perlu diberikan kartu tanda pemilik kendaraan terutama motor, karena banyak pelanggan yang merasa tidak aman jika menaruh motor di gerai tersebut. Dan pada variable empati, gerai Dunkin Donuts terdiri dari 2 lantai, sebaiknya pada lantai atas dipasangkan bel untuk mempermudah pelanggan dalam menghubungi karyawan.
Hasil analisis IPA menyatakan bahwa terdapat beberapa atribut dalam variable yang berada pada kuadran I yang harus diperbaiki. Adapun atribut yang harus diperbaiki untuk meningkatkan kepuasan konsumen adalah toilet yang tersedia, kecepatan ketepatan dan kesediaan karyawan dalam menangani keluhan pelanggan, dan perhatian karyawan pada konsumen yang membutuhkan pelayanan. Atribut-atribut ini harus segera diperbaiki untuk menambah kepuasan konsumen Dunkin Donuts.

Atribut yang sudah berada pada kuadran II dan III harus dipertahankan dan ditingkatkan, serta pada kuadran IV sebaiknya tidak terlalu gencar dilakukan oleh pihak Dunkin Donuts, karena konsumen menganggap atribut tersebut tidak penting, sedangkan kinerja yang diberikan termasuk berlebihan, lebih baik Dunkin Donuts memberikan kinerja terbaiknya pada kuadran lain yang bisa membuat konsumen merasa puas dengan Dunkin Donuts.

\section{KESIMPULAN}

Terdapat 3 Atribut yang ada dalam kuadran I. Adapun atribut yang harus diperbaiki untuk meningkatkan kepuasan konsumen adalah toilet yang tersedia, kecepatan ketepatan dan kesediaan karyawan dalam menangani keluhan pelanggan, dan perhatian karyawan pada konsumen yang membutuhkan pelayanan. Terdapat 8 atribut yang ada dalam kuadran II. Atribut-atribut yang terdapat pada kuadran ini harus dipertahankan oleh perusahaan. Kuadran III merupakan kuadran dengan prioritas rendah karena memuat atribut-atribut yang dianggap kurang penting oleh pelanggan dan pada kenyataannya kinerjanya tidak terlalu istimewa. Terdapat 6 atribut dalam kuadran III. Atribut pada kuadran IV mempunyai tingkat kepentingan yang rendah, tetapi memiliki tingkat pelaksanaan kinerja tinggi. Terdapat 1 Atribut yang ada dalam kuadran IV.

Nilai CSI yang diperoleh adalah $86,76 \%$. Hal ini menggambarkan pelanggan Dunkin Donuts merasa sangat puas dengan kinerja pelayanan yang diberikan oleh gerai Dunkin Donuts cabang Gading Serpong. 


\section{DAFTAR PUSTAKA}

[1] Adi, A. F. 2012. Analisis Pengaruh Harga, Kualitas Produk, dan Kualitas Pelayanan Terhadap Kepuasan Konsumen. Semarang: $\quad$ Skripsi Universitas Diponegoro.

[2] Adriani, N. 2012. Analisis Tingkat Kepuasan Konsumen Terhadap Kualitas Pelayanan Dunkin Donuts Cafe Metropolitan. Jakarta: Skripsi Universitas Gunadarma.

[3] Anggraini, L. D., Deoranto, P., \& Ikasari, D. M. (2015). Analisis Persepsi Konsumen menggunakan Metode Importance Perfomance Analysis dan Customer Satisfaction Index. Jurnal Industri . 4 (2), 74-81.

[4] Arikunto, Suharsimi. 2006. Prosedur Penelitian Suatu Pendekatan Praktik. Jakarta : Rineka Cipta.

[5] Green, S.B. 1991. How Many Subjects Does It Take To Do a Regression Analysis? Multivariate Behavioral Research. 26 (3), 499-510.

[6] Mowen, C dan Minor M (2002). Perilaku Konsumen. Edisi Kelima. Jakarta: Erlangga.

[7] Parasuraman A, Zeithaml V, Berry L. 1985. A conceptual Model of Service Quality and Its Implication for Future Research. Journal of Marketing. 49(4), 41-50.

[8] Pohandry, A., Sidarto, \& Winarni. (2013). Analisis Tingkat Kepuasan Pelanggan Dengan Menggunakan Metode Customer Satisfaction Index dan Importance Perfomance Analysis Serta Service Quality. Jurnal REKAVASI. 1 (1) , 21-29.

[9] Rangkuti, F. (2011). Riset Pemasaran. Jakarta: Gramedia.
[10] Rijanto, O. A. (2014). Analisis Customer Satisfaction Index (CSI) Produk dan Kepuasan Pelanggan Terhadap Kualitas Produk UMKM Rumput Laut Situbondo. Media Mahardika. 12(3) , 73-84.

[11\} Santoso. (2011). Persepsi Konsumen Terhadap Kualitas Bakpao Telo Dengan Metode Importance Performance Analysis (IPA). Jurnal Teknologi Pertania,. 12 (1) : 9.

[12] Sasongko, F., \& Subagjo, H. (2013). Pengaruh Kualitas Layanan Terhadap Kepuasan Pelanggan Restoran Ayam Penyet Ria. Jurnal Manajemen pemasaran Petra.1 (2) , 1-7.

[13] Selvakumar, J. (2015). Impact of Service Quality on Customer Satisfaction in Public Sector and Private Sector Banks. Journal SMS Varanasi Vol. 8 No. 1, 1-12.

[14] Utami, I. A., \& Jatra, I. M. (2015). Pengaruh Kualitas Layanan Terhadap Kepuasan Pelanggan Restoran Baruna Sanur. Jurnal Manajemen Umud Vol.4 No. 7 , 1-17.

[15] Wicaksono, Arie. (2017). Strategi Pemasaran dengan menggunakan Analisis SWOT Tanpa Skala Industri Pada PT X Di Jakarta. Jurnal Manajemen Industri dan Logistik, 1(2), 106-112.

[16] Winarno, Heru dan Absor. Analisis Kualitas Pelayanan dengan metode Service Quality (SERVQUAL) dan Importance Performance Analysis (IPA) Pada PT Media Purna Engineering. Jurnal Manajemen Industri dan Logistik, 1(2), 67-77 